\title{
Laparoscopic Transperitoneal Simple, Radical and Partial Nephrectomy: A Single Center Experience
}

\section{Laparoskopik Transperitoneal Basit, Radikal ve Parsiyel Nefrektomi: Tek Merkez Klinik Tecrübemiz}

\author{
(D) Önder Çınar1, (D) Engin Denizhan Demirkıran11, (D) Ersan Bulut1, (D) Mustafa Suat Bolat², (D) Bülent Akduman¹, (D) Necmettin Aydın \\ Mungan 1 \\ 1Zonguldak Bülent Ecevit University, Department of Urology, Zonguldak, Turkiye \\ 2Samsun Gazi State Hospital, Clinic of Urology, Samsun, Turkiye
}

\section{What's known on the subject? and What does the study add?}

Laparoscopic surgery has become a standard technique for better results for both oncologic and non-oncologic diseases, especially in urology, as in other disciplines. The higher the surgeon's experience in laparoscopic surgery, the shorter the operative time, the lesser the blood loss and the shorter the hospital stay. Currently, as the urologists gain experience in laparoscopy, they perform more complex operations such as partial nephrectomy in a shorter time, with less blood loss and complications. It should be kept in mind that there may be more perirenal adhesions in laparoscopic simple nefrectomy patients and care should be taken for possible complications.

\begin{abstract}
Objective: To present our initial experience on laparoscopic transperitoneal nephrectomies and to report the perioperative and postoperative outcomes in patients with kidney tumor.

Materials and Methods: We retrospectively evaluated clinical data, laboratory results and radiological findings of 40 patients who underwent laparoscopic renal surgery performed by a single surgeon in a single center between November 2017 and May 2019. Thoracoabdominopelvic computed tomography was performed in all patients.

Results: A total of 40 patients (26 males (65\%), 14 females (35\%) with a median age of 58.7 years underwent laparoscopic transperitoneal nephrectomy. Sixteen patients underwent laparoscopic simple nephrectomy (LSN) for nonfunctional kidney, 20 patients with solid renal tumors underwent laparoscopic radical nephrectomy (LRN), and four patients underwent laparoscopic partial nephrectomy (LPN) for solid renal mass. The mean operative time was $207.9 \pm 79.1,218.9 \pm 57.5$ and $175.0 \pm 75.0$ minutes for $L S N$, LRN and LPN, respectively. The mean length of hospital stays was $3.0 \pm 1.3,2.7 \pm 0.6$ and $2.7 \pm 1.5$ days, respectively. Conversion to open surgery was done in 2 patients who underwent LRN and in two patients who underwent LSN due to intraoperative bleeding and intraperitoneal adhesions, respectively. We experienced postoperative complication only in one patient (2.5\%) who underwent LSN.

Conclusion: Advances in technology and surgical experience have led to an increase in laparoscopic kidney surgery even for advanced renal tumors. Serious complications may occur mainly in the early stages of the learning curve, but complication rates and operative time significantly decrease by the surgeons' experience. Complicated and more extensive tumors make surgeons more experienced in advanced laparoscopic treatment techniques. Keywords: Complication, Experience, Laparoscopy, Renal tumor
\end{abstract}

Öz

Amaç: Laparoskopik transperitoneal nefrektomi konusunda ilk deneyimimizi sunmak ve böbrek tümörü olan hastalarda perioperatif ve postoperatif sonuçları bildirmek.

Correspondence: Önder Çınar MD, Zonguldak Bülent Ecevit University, Deparment of Urology, Zonguldak, Turkiye E-mail: drondercinar@gmail.com ORCID-ID: orcid.org/0000-0002-0107-5843

Received: $30.08 .2019 \quad$ Accepted: 28.09.2019

Cite this article as: Çınar Ö, Denizhan ED, Bulut E, Bolat MS, Akduman B, Mungan NA. Laparoscopic Transperitoneal Simple, Radical and Partial Nephrectomy: A Single Center Experience. J Urol Surg 2020;7(1):16-20.

${ }^{\circ}$ Copyright 2020 by the Association of Urological Surgery / Journal of Urological Surgery published by Galenos Publishing House. 
Gereç ve Yöntem: Kasım 2017-Mayıs 2019 tarihleri arasında tek bir merkezde aynı cerrah tarafından laparoskopik böbrek cerrahisi ile ameliyat edilen 40 hastanın klinik verilerini, laboratuvar sonuçlarını ve radyolojik bulgularını retrospektif olarak değerlendirdik. Torakoabdominopelvik bilgisayarlı tomografi tüm hastalar için rutin olarak yapıldı.

Bulgular: Toplam kırk hastaya (26 erkek (\%65), 14 kadın (\%35) ortanca yaş 58,7 yıl) laparoskopik transperitoneal nefrektomi uygulandı. Hastaların 16'sına fonksiyonel olmayan böbrek için laparoskopik basit nefrektomi (LBN) uygulandı; solid böbrek tümörü olan 20 hastaya laparoskopik radikal nefrektomi (LRN), dört hastaya da solid böbrek kitlesi için laparoskopik parsiyel nefrektomi (LPN) uygulandı. Ortalama operasyon süreleri LBN, LRN ve LPN için sırasıyla $207,9 \pm 79,1,218,9 \pm 57,5$ ve $175 \pm 75,0$ dakikaydı. Ortalama hastanede kalış süresi sırasıyla $3,0 \pm 1,3,2,7 \pm 0,6$ ve $2,7 \pm 1,5$ gündü. LRN uygulanan iki hastada ve LBN yapılan iki hastada, sırasıyla intraoperatif kanama ve intraperitoneal adezyonlar nedeniyle açık nefrektomiye geçildi. Postoperatif komplikasyon sadece LBN uygulanan bir hastada $(\% 2,5)$ saptandı.

Sonuç: Teknoloji ve cerrahi tecrübedeki gelişmeler ile laparoskopik böbrek cerrahisi ileri böbrek tümörleri için bile tercih edilen yöntem haline gelmiştir. Özellikle öğrenme eğrisinin erken aşamalarında ciddi komplikasyonlar ortaya çıkabilir, ancak komplikasyon oranları ve çalışma süreleri cerrahın tecrübesiyle önemli ölçüde azalır. Komplike ve daha büyük tümörler, ileri laparoskopik tedavi teknikleri için cerrahları daha deneyimli hale getirmektedir.

Anahtar Kelimeler: Laparoskopi, Böbrek tümörü, Tecrübe, Komplikasyon

\section{Introduction}

The European Association of Urology and the American Urological Association recommend the surgical approach as a primary treatment modality for kidney tumors $(1,2)$. Evolution in minimally invasive treatment techniques has led to laparoscopic surgery, the standard treatment procedure for stage T1 kidney tumors $(3,4)$. Laparoscopic nephrectomy (LN) offers oncological results similar to those of open nephrectomy with the advantages of shorter hospital stay, faster recovery, less pain and blood loss $(5,6)$.

In this study, we aimed to report our experience and postoperative outcomes in patients who underwent laparoscopic transperitoneal nephrectomy due to nonfunctioning kidney or kidney tumor.

\section{Materials and Methods}

After receiving Institutional Board approval from the Clinical Research and Ethics Committee of Zonguldak Bülent Ecevit University (Zonguldak, Turkiye) (33479383/37), we retrospectively reviewed the medical record of 40 patients with different pathologies who underwent a laparoscopic transperitoneal simple, radical or partial nephrectomy between November 2017 and May 2019. We recorded the demographic characteristics, such as gender and age, as well as body mass index, type of surgery, American Society of Anesthesiologists risk, preoperative and postoperative hemoglobin and creatinine levels, operative time, postoperative drainage, hospital stay and histopathological diagnoses, in addition to R.E.N.A.L nephrometry scores in those with kidney tumor.

In the R.E.N.A.L nephrometry scoring system; (R) represents maximum tumor radius, (E) endophytic/exophytic properties of the mass, (N) tumor distance to the collecting system, (A) anterior/posterior descriptor and, (L) represents the location relative to the polar line. Each parameter was scored from 1 to 3 according to the anatomy of the tumor, and the total score was calculated. A total score of 4-6 means low, 7-9 intermediate and 10-12 high tumor complexity.

\section{Statistical Analysis}

The Statistical Package for the Social Sciences v. 18.0 (SPSS Inc, Chicago, IL, USA) was used for statistical analysis. Data were given as mean \pm standard deviation, percentages, or numbers. A $p$ value $<0.05$ was accepted as significant.

\section{Surgical Procedure}

We performed transperitoneal laparoscopic surgery with the patient placed in 70-degree lateral decubitus position. A $12 \mathrm{~mm}$ optical camera port was inserted $5 \mathrm{~cm}$ lateral to the level of the umbilicus after $20 \mathrm{mmHg}$ pneumoperitoneum was created using a Veress needle. The second $10 \mathrm{~mm}$ trocar was placed subxiphoidally and, finally, a $5 \mathrm{~mm}$ trocar was placed about two $\mathrm{cm}$ medial and superior to the anterior superior iliac crest to create a triangular shape under direct vision for the left side. For right-sided tumors, we used an additional $5 \mathrm{~mm}$ port for liver retraction. In the intraabdominal pressure of $12 \mathrm{mmHg}$, the colon was medialized with the help of a grasper and scissors over the Toldt line. The renal artery and vein were dissected and separately clipped using Hem-o-lok (Weck Closure Systems; Research Triangle Park, NC) clips. The kidney was released from the surrounding tissues by dissecting with a LigaSure device. For partial nephrectomy, after renal pedicle dissection, we clamped the main renal artery using a bullog clamp (Figure 1a) and resected the tumor with safe margins. Using a 2-0 absorbable polyglactin suture, we closed the renal parenchyma in a running fashion (Figure 1b). The bulldog clip was removed, the renal artery was opened, and the intraabdominal pressure was decreased to $5 \mathrm{mmHg}$ to control bleeding. We removed the specimens via the trocar incision using an endo bag (Endo Catch Gold, Medtronic, MN) and placed a drain at the surgery site. In the early postoperative period, we used a patient-controlled analgesia pump and paracetamol for pain relief. 


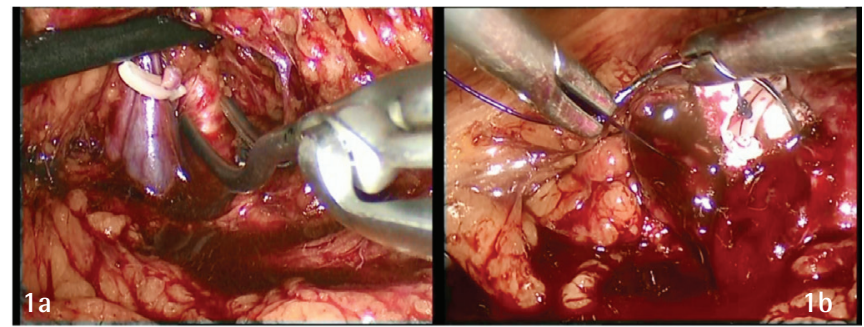

Figure 1. Renal artery was clamped using a bulldog clamp (1a) and renal parenchyma was closed in a running fashion using a 2-0 absorbable polyglactin suture $(1 b)$

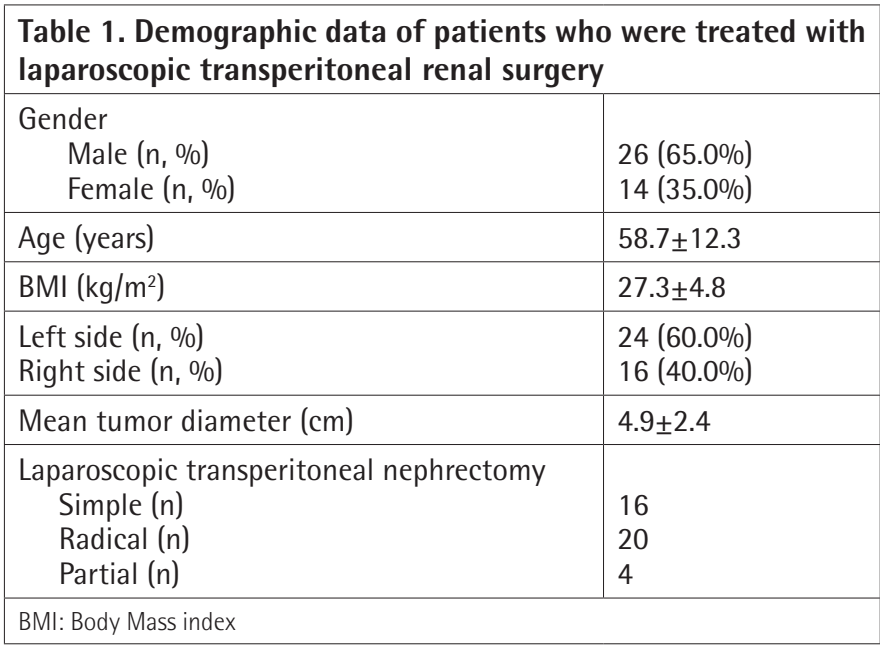

\section{Results}

A total of 40 patients were included in the study. Twenty-six were male (65\%) and 14 were female (35\%). The mean age was $58.7 \pm 12.3$ years, the mean body mass index was $27.3 \pm 4.8 \mathrm{~kg} / \mathrm{m} 2$ and the mean tumor diameter was $4.9 \pm 2.4 \mathrm{~cm}$. Sixteen patients had right-sided (40\%), and 24 had left-sided disease (Table 1).

Low, moderate and high total R.E.N.A.L nephrometry scores were recorded in eight, seven and nine patients, respectively. The mean operative time was $207.9 \pm 79.1,218.9 \pm 57.5$ and $175.0 \pm 75.0$ minutes for simple nephrectomy, radical nephrectomy and partial nephrectomy, respectively. After mobilization of the patients on postoperative day 1, we removed the urethral Foley catheter. The mean length of hospital stay was $5.0 \pm 2.8,3.7 \pm 0.9$ and $3.7 \pm 2.0$ days and the mean duration of drain use stays was $3.0 \pm 1.3,2.7 \pm 0.6$ and $2.7 \pm 1.5$ days for laparoscopic simple nephrectomy (LSN), laparoscopic radical nephrectomy (LRN) and laparoskopik parsiyel nefrektomi (LPN), respectively (Table 2).

Sixteen patients underwent LSN for nonfunctioning kidney, 20 underwent LRN, and 4 patients underwent LPN for kidney tumor. Conversion to open surgery was needed in four patients $(10 \%)$ due to intraabdominal adhesions or bleeding (due to significant vascular injury $(n=1)$, splenic laceration $(n=1)$, and in remaining two patients, due to significant intraperitoneal adhesions. Intraoperatively, 1 patient with renal artery injury

Table 2. Perioperative and postoperative findings of patients who were treated with laparoscopic transperitoneal renal surgery

\begin{tabular}{|c|c|c|c|}
\hline & $\operatorname{LSN}(n=16)$ & LRN $(\mathrm{n}=\mathbf{2 0})$ & LPN $(n=4)$ \\
\hline Operation time $(\mathrm{min}),($ mean \pm standard deviation) & $207.9 \pm 79.1$ & $218.9 \pm 57.5$ & $175.0 \pm 75.0$ \\
\hline Hospital stay (days) (mean \pm standard deviation) & $5.0 \pm 2.8$ & $3.7 \pm 0.9$ & $3.7 \pm 2.0$ \\
\hline Mean drainage (days), (mean \pm standard deviation) & $3.0 \pm 1.3$ & $2.7 \pm 0.6$ & $2.7 \pm 1.5$ \\
\hline $\begin{array}{l}\text { Mean hemoglobine level }(\mathrm{g} / \mathrm{dL}),(\text { mean } \pm \text { standard deviation) } \\
\text { Preoperative } \\
\text { Postoperative }\end{array}$ & $\begin{array}{l}14.4 \pm 1.7 \\
13.2 \pm 1.8\end{array}$ & $\begin{array}{l}13.7 \pm 1.3 \\
12.3 \pm 1.2\end{array}$ & $\begin{array}{l}14.1 \pm 0.7 \\
12.5 \pm 0.5\end{array}$ \\
\hline $\begin{array}{l}\text { Mean creatine level }(\mathrm{mg} / \mathrm{dL}),(\text { mean } \pm \text { standard deviation) } \\
\text { Preoperative } \\
\text { Postoperative }\end{array}$ & $\begin{array}{l}1.0 \pm 0.2 \\
1.0 \pm 0.3\end{array}$ & $\begin{array}{l}0.8 \pm 0.2 \\
1.0 \pm 0.2\end{array}$ & $\begin{array}{l}0.7 \pm 0.2 \\
0.8 \pm 0.1\end{array}$ \\
\hline Mean ASA1 score (mean \pm standard deviation) & $2.0 \pm 0.2$ & $2.4 \pm 0.6$ & $2.5 \pm 1.0$ \\
\hline Mean R.E.N.A.L nephrometry score (mean \pm standard deviation) & - & $8.8 \pm 1.9$ & $4.5 \pm 0.5$ \\
\hline $\begin{array}{l}\text { Total intraoperative complications (n) } \\
\text { Renal arterial injury (n) } \\
\text { Splenic injury (n) }\end{array}$ & $\begin{array}{l}- \\
- \\
-\end{array}$ & $\begin{array}{l}2 \\
1 \\
1\end{array}$ & $\begin{array}{l}- \\
- \\
-\end{array}$ \\
\hline $\begin{array}{l}\text { Conversion to open surgery (n) } \\
\text { Due to adhesions (n) } \\
\text { Due to visceral injury (n) } \\
\text { Due to vessel injury (n) }\end{array}$ & $\begin{array}{l}2 \\
2 \\
- \\
-\end{array}$ & $\begin{array}{l}2 \\
- \\
1 \\
1\end{array}$ & $\begin{array}{l}- \\
- \\
- \\
-\end{array}$ \\
\hline $\begin{array}{l}\text { Postoperative complications (n) } \\
\text { Duodenal perforation ( })\end{array}$ & $\begin{array}{l}1 \\
1\end{array}$ & $\begin{array}{l}- \\
-\end{array}$ & $\begin{array}{l}- \\
-\end{array}$ \\
\hline
\end{tabular}




\begin{tabular}{|l|l|l|l|}
\hline $\begin{array}{l}\text { Table 3. Pathological results of the laparoscopic } \\
\text { transperitoneal renal surgeries }\end{array}$ \\
\hline & LSN (n=16) & LRN (n=20) & LPN (n=4) \\
\hline Benign (n) & 16 & - & 1 \\
\hline Oncocytoma (n) & - & 3 & 1 \\
\hline RCC' & - & & \\
Clear cell (n) & 9 & 2 \\
Papillary (n) & - & 2 & - \\
Chromophobe (n) & - & 5 & - \\
Carcinosarcoma (n) & - & 1 & - \\
\hline RCC': Renal cell carcinoma, LSN: Laparoscopic simple nephrectomy, LRN: Laparoscopic \\
radical nephrectomy, LPN: Laparoscopic partial nephrectomy \\
\hline
\end{tabular}

received 5 units and 1 patient with splenic injury received 2 units of blood.

In a patient who underwent right LSN due to nonfunctioning kidney with stone formation, duodenal perforation occurred in the postoperative second day which was successfully repaired (2.5\%). Histopathological evaluation revealed benign lesions in 4 patients (16.6\%) and malignant lesions in 20 (83.3\%) (Table 3).

\section{Discussion}

The laparoscopic approach for the treatment of $\mathrm{T} 1$ renal tumors has been accepted as the standard surgical method by the development of laparoscopic devices in addition to the laparoscopic experience. LN has been shown to have advantages such as faster recovery, fewer painkillers, early mobilization, shorter hospital stay and early oral feeding compared to open surgery $(5,6)$. Shorter mean time to normal activity (3.6 versus 8.1 weeks) and shorter mean time to full recovery ( 8.2 versus 29.3 weeks) have been reported for LN compared to open nephrectomy with similar oncological outcomes $(7,8,9,10)$.

All patients underwent a standard transperitoneal laparoscopic approach in our clinic with the advantages of larger working space, presence of prominent anatomical landmarks, and better maneuverability due to the distance between ports. Retroperitoneal laparoscopy provides shorter hospital stay and lower complication rates. It can easily be applied in patients who had previous abdominal surgery with similar oncological outcomes, and it has also the advantage of early renal hilar control (11). However, working in a small space is the main limiting factor (12). The surgeon's experience and preference is the most critical factor in choosing a transperitoneal or retroperitoneal approach. Because of our increasing experience in transperitoneal laparoscopy, we routinely use the transperitoneal approach in our clinic.

In 2010, Demir et al. (13) reported their first experiences of laparoscopic approach on 32 patients with the mean operative time of 181 and 179 min for LRN and LSN, respectively. In their study including $482 \mathrm{LN}$ procedures (344 via transperitoneal approach and 138 via retroperitoneal approach) performed in 14 centers, Rassweiler et al. (14) found that the mean operative time for transperitoneal approach was $178 \mathrm{~min}$. The longest operative time for laparoscopic radical nephrectomy was given as 300 minutes in the literature $(15,16,17)$. The mean operative time in our study was consistent with the literature (200.6 min).

Four patients required conversion to open surgery due to severe intraperitoneal adhesions, vascular injury and splenic laceration $(10 \%)$. However, all the open conversions occurred in the initial stage of laparoscopic surgery. The rate of conversion to open surgery has been reported to be between $14 \%$ and $4 \%$ in the literature $(18,19,20)$. In our study, perirenal adhesions and duodenal perforation were mostly observed in LSN patients. Akkoc et al. (21) reported two vascular injuries (7.1\%) in twenty eight LSN patients. In addition to the surgeon's experience, the higher the total R.E.N.A.L nephrometry score, the higher the likelihood of vascular complications. Considering that the number of patients with moderate and high R.E.N.A.L nephrometry score was 16, it could be assumed that these patients were quite complicated cases. The rate of vascular injury complication associated with laparoscopic surgery has been reported to be $0.03 \%-2.7 \%(22,23,24)$. Nevertheless, in the present study, the rate of significant vascular damage was $2.5 \%$, which was consistent with the literature.

\section{Study Limitations}

Initial experience and postoperative outcomes of patients who underwent laparoscopic transperitoneal simple, radical or partial nephrectomy were reported in this study. However, this study has some limitations including

1) Small sample size,

2) Lack of long-term follow-up,

3) The study was not designed as randomized controlled study.

\section{Conclusion}

With the advances in technology and surgical experience, LN has become the preferred method even for advanced renal tumors. Serious complications may occur mainly in the early stages of the learning curve, but complication rates and operative time significantly decrease by the surgeons' experience. Complicated and more extensive tumors make surgeons more experienced in advanced laparoscopic treatment techniques

\section{Ethics}

Ethics Committee Approval: Institutional Board Approval was obtained from Clinical Research and Ethics Committee of Zonguldak Bülent Ecevit University (33479383/37). 
Informed Consent: Consent form was filled out by all participants.

Peer-review: Internally peer-reviewed.

\section{Authorship Contributions}

Surgical and Medical Practices: Ö.Ç., E.B., E.D.D., B.A., N.A.M., Concept: Ö.Ç., Design: Ö.Ç., Data Collection or Processing: Ö.Ç., M.S.B., E.B., E.D.D., Analysis or Interpretation: Ö.Ç., M.S.B., E.B., Literature Search: Ö.Ç., E.D.D., M.S.B., Writing: Ö.Ç., E.D.D., M.S.B.

Conflict of Interest: The authors report no conflicts of interest.

Financial Disclosure: The authors declared that this study received no financial support

\section{References}

1. Ljungberg B, Bensalah $K$, Canfield $S$, Dabestani $S$, Hofmann $F$, Hora $M$, Kuczyk MA, Lam T, Marconi L, Merseburger AS, Mulders P, Powles T, Staehler M, Volpe A, Bex A. EAU guidelines on renal cell carcinoma: 2014 update. Eur Urol 2015;67:913-924.

2. Campbell S, Uzzo RG, Allaf ME, Bass EB, Cadeddu JA, Chang A, Clark PE, Davis BJ, Derweesh IH, Giambarresi L, Gervais DA, Hu SL, Lane BR, Leibovich BC, Pierorazio PM. Renal Mass and Localized Renal Cancer: AUA Guideline. J Urol 2017:198:520-529.

3. Van Poppel H, Becker F, Cadeddu JA, Gill IS, Janetschek G, Jewett MA, Laguna MP, Marberger M, Montorsi F, Polascik TJ, Ukimura 0, Zhu G. Treatment of localised renal cell carcinoma. Eur Urol 2011;60:662-672.

4. Nguyen CT, Campbell SC, Novick AC. Choice of operation for clinically localized renal tumor. Urol Clin North Am 2008;35:645-655.

5. Liu G, Ma Y, Wang S, Han X, Gao D. Laparoscopic Versus Open Radical Nephrectomy for Renal Cell Carcinoma: a Systematic Review and MetaAnalysis. Transl Oncol 2017;10:501-510.

6. Liu F, Guo W, Zhou X, Ding Y, Ma Y, Hou Y, Kong X, Wang Z. Laparoscopic versus open nephroureterectomy for upper urinary tract urothelial carcinoma: A systematic review and meta-analysis. Medicine (Baltimore) 2018;97:e11954.

7. Nadu A, Mor Y, Chen J, Sofer M, Golomb J, Ramon J. Laparoscopic nephrectomy: initial experience in Israel with 110 cases. Isr Med Assoc J 2005;7:431-434.

8. Hemal AK, Kumar A, Kumar R, Wadhwa P, Seth A, Gupta NP. Laparoscopic versus open radical nephrectomy for large renal tumors: a longterm prospective comparison. J Urol 2007;177:862-866.

9. Brewer K, O'Malley RL, Hayn M, Safwat MW, Kim H, Underwood W 3rd, Schwaab T. Perioperative and renal function outcomes of minimally invasive partial nephrectomy for T1b and T2a kidney tumors. J Endourol 2012;26:244-248

10. Sprenkle PC, Power N, Ghoneim T, Touijer KA, Dalbagni G, Russo P, Coleman JA. Comparison of open and minimally invasive partial nephrectomy for renal tumors 4-7 centimeters. Eur Urol 2012;61:593-599.

11. Ha US, Hwang TK, Kim YJ, Oh TH, Jeon YS, Lee W, Lim JS, Lee TY, Choi Y, Park SK, Byun SS. Comparison of oncological outcomes of transperitoneal and retroperitoneal laparoscopic radical nephrectomy for the management of clear-cell renal cell carcinoma: a multi-institutional study. BJU Int 2011;107:1467-1472.

12. McAllister M, Bhayani SB, Ong A, Jaffe W, Malkowicz SB, VanArsdalen $K$, Chow GK, Jarrett TW. Vena caval transection during retroperitoneoscopic nephrectomy: report of the complication and review of the literature. J Urol 2004;172:183-185.

13. Demir Ö, Öztürk B, Egriboyun S, Esen A. Kliniğimizde Laparoskopik Cerrahide Illk Deneyimlerimiz Ve Öğrenme Süreci. Dokuz Eylül Tıp Fakültesi Dergisi 2010;24:105-112.

14. Rassweiler J, Fornara $P$, Weber $M$, Janetschek $G$, Fahlenkamp $D$, Henkel $T$, Beer M, Stackl W, Boeckmann W, Recker F, Lampel A, Fischer C, Humke $\mathrm{U}$, Miller K. Laparoscopic nephrectomy: the experience of the laparoscopic working group of the German Urological Association. J Urol 1998;160:1821.

15. Abbou CC, Cicco A, Gasman D, Hoznek A, Antiphon P, Chopin DK, Salomon L. Retroperitoneal laparoscopic versus open radical nephrectomy. J Urol 1999;161:1776-1780

16. Ono $Y$, Kinukawa T, Hattori R, Gotoh M, Kamihira O, Ohshima S. The longterm outcome of laparoscopic radical nephrectomy for small renal cell carcinoma. J Urol 2001;165:1867-1870.

17. Chan DY, Cadeddu JA, Jarrett TW, Marshall FF, Kavoussi LR. Laparoscopic radical nephrectomy: cancer control for renal cell carcinoma. J Urol 2001;166:2095-2099.

18. Gill IS, Meraney AM, Schweizer DK, Savage SS, Hobart MG, Sung GT, Nelson D, Novick AC. Laparoscopic radical nephrectomy in 100 patients: a single center experience from the United States. Cancer. 2001;92:1843-1855.

19. Soulie M, Seguin P, Richeux L, Mouly P, Vazzoler N, Pontonnier F, Plante P. Urological complications of laparoscopic surgery: experience with 350 procedures at a single center. J Urol 2001;165:1960-1963.

20. Simon SD, Castle EP, Ferrigni RG, Lamm DL, Swanson SK, Novicki DE, Andrews PE. Complications of laparoscopic nephrectomy: the Mayo clinic experience. J Urol 2004;171:1447-1450.

21. Akkoc A, Topaktas R, Aydin C, Altin S, Girgin R, Yagli OF, Sentürk AB, Metin A. Which intraperitoneal insufflation pressure should be used for less postoperative pain in transperitoneal laparoscopic urologic surgeries? Int Braz J Urol 2017:43:518-524.

22. Gill IS, Kavoussi LR, Clayman RV, Ehrlich R, Evans R, Fuchs G, Gersham A, Hulbert JC, McDougall EM, Rosenthal T, Schuessler WW, Shepard T. Complications of laparoscopic nephrectomy in 185 patients: a multiinstitutional review. J Urol 1995;154:479-483.

23. Siqueira Jr TM, Kuo RL, Gardner TA, Paterson LH, Stevens LH, Lingeman JE, Koch MO, Shalhav AL. Major complications in 213 laparoscopic nephrectomy cases: the Indianapolis experience. J Urol 2002;168:1361-1365.

24. Colombo Jr JR, Haber GP, Jelovsek JE, Nguyen M, Fergany A, Desai MM, Kaouk JH, Gill IS. Complications of laparoscopic surgery for urological cancer: a single institution analysis. J Urol 2007;178:786-791. 